\section{Additional response to the correspondence: 'Switching from the bio-originators to biosimilar: is it premature to recommend this procedure?' by Cantini and Bennuci}

We read with great interest Cantini and Benucci's response to our letter. ${ }^{1}$ However, we would like to add some points to the debate.

To date and to our knowledge, every single clinical trial investigating efficacy and safety of biosimilars in rheumatology using a double-blinded design has failed to report any clinical difference with the original biologic. The double-blinded controlled trial NOR-SWITCH as well as open-label extension studies such as PLANETRA investigating efficacy and safety of the switch from original to biosimilar infliximab also failed to report any difference. $^{2}{ }^{3}$ These studies unequivocally condone the grade $1 \mathrm{~b}$ recommendation 6 regarding the efficacy and safety of the switch published in the journal. ${ }^{4}$

Cantini and Benucci's concern emerged from the Danish Biologic Registry (DANBIO), which reported a borderline significant lower retention rate at 1 year post-mandatory non-medical switch in the adjusted (but not the crude) analysis: $86.8 \%$ versus $83.4 \%(\mathrm{P}=0.03) .{ }^{56}$ Analysis of the literature and the work we conducted has led us to believe that the lower retention rate of the biosimilar after a switch might not be due to the biosimilar itself but rather by patient perception together with the way health authorities and physicians handle the switch.?

In Denmark, a national consensus led to a non-medical switch of all patients without that patient (nor physician) had any say. A non-medical switch more frequently leads to negative outcomes than medical switch, ${ }^{8}$ and not taking into account patient opinion is more likely to be counterproductive. Interestingly, in a randomised study evaluating originator etanercept versus placebo in rheumatoid arthritis, 24 weeks' clinical response was lower (71.4\% of ACR20 in the treated group) than in the study comparing originator and a biosimilar etanercept (86.7\% and 93.3\% ACR20, respectively). ${ }^{9} 10$ This suggests that the eventuality of placebo treatment affects the efficacy of the verum treatment. We believe that similar mechanisms are at play after offering the switch to a biosimilar. More work is needed to better understand patient perspective on biosimilars and as to how to address the switch properly. Yet, this should not refrain physicians from offering the switch, maybe at first to selected patients.

Concerning the economic considerations, we politely disagree with our colleagues since the savings will be accomplished on the proportion of patients continuing the biosimilar, which is the large majority of patients: $83.4 \%$ in DANBIO and $72 \%$ in our study. ${ }^{57}$ As we discussed earlier, ${ }^{11}$ the expected drop-out patients will need to be switched to another biologic or targeted synthetic disease-modifying antirheumatic drug (bDMARD or tsDMARD). The small proportion of excess drop-out (which clinical characteristics were not detailed in DANBIO) are characterised by subjective symptoms and can be rescued by originator resumption. ${ }^{72}$ With this in mind, we hardly see how this strategy would not be generating significant savings. As for the fact that dose tapering is a cost-effective strategy in rheumatic diseases, we totally agree with our colleagues. We would, however, like to add that dose tapering can also be conducted with biosimilars, thus generating even higher savings and turning a half-full glass into a full glass.

\section{Marc Scherlinger, ${ }^{1}$ Thierry Schaeverbeke ${ }^{2}$}

${ }^{1}$ Service de Rhumatologie, Centre Hospitalier Universitaire de Bordeaux, Bordeaux, France

${ }^{2}$ Université de Bordeaux, Bordeaux, France

Correspondence to Dr Marc Scherlinger, Service de Rhumatologie, Centre Hospitalier Universitaire de Bordeaux, 33000 Bordeaux, France: marc.scherlinger@chu-bordeaux.fr

Contributors MS and TS equally contributed to writing the correspondence response.

Competing interests None declared.

Patient consent Not required.

Provenance and peer review Not commissioned; internally peer reviewed.

(c) Article author(s) (or their employer(s) unless otherwise stated in the text of the article) 2019. All rights reserved. No commercial use is permitted unless otherwise expressly granted.

\section{Check for updates}

To cite Scherlinger M, Schaeverbeke T. Ann Rheum Dis 2019;78:e26.

Received 2 March 2018

Accepted 5 March 2018

Published Online First 13 March 2018

\section{Sinked}

- http://dx.doi.org/10.1136/annrheumdis-2018-213044

Ann Rheum Dis 2019:78:e26. doi:10.1136/annrheumdis-2018-213342

\section{REFERENCES}

1 Cantini F, Benucci M. Response to: 'Seeing the glass either half full or half empty: response to the correspondence 'Switching from the bio-originators to biosimilar: is it premature to recommend this procedure?" by Scherlinger and Schaeverbeke. Ann Rheum Dis 2019;78:e25.

2 Jørgensen $\mathrm{KK}$, Olsen IC, Goll GL, et al. Switching from originator infliximab to biosimilar CT-P13 compared with maintained treatment with originator infliximab (NOR-SWITCH): a 52-week, randomised, double-blind, non-inferiority trial. Lancet 2017:389:2304-16.

3 Yoo DH, Prodanovic N, Jaworski J, et al. Efficacy and safety of CT-P13 (biosimilar infliximab) in patients with rheumatoid arthritis: comparison between switching from reference infliximab to CT-P13 and continuing CT-P13 in the PLANETRA extension study. Ann Rheum Dis 2017:76:355-63.

4 Kay J, Schoels MM, Dörner T, et al. Consensus-based recommendations for the use of biosimilars to treat rheumatological diseases. Ann Rheum Dis 2018;77:165-74.

5 Glintborg B, Sørensen IJ, Loft AG, et al. A nationwide non-medical switch from originator infliximab to biosimilar CT-P13 in 802 patients with inflammatory arthritis: 1-year clinical outcomes from the DANBIO registry. Ann Rheum Dis 2017;76:1426-31.

6 Cantini F, Benucci M. Switching from the bio-originators to biosimilar: is it premature to recommend this procedure? Ann Rheum Dis 2019;78:e23.

7 Scherlinger M, Germain V, Labadie C, et al. Switching from originator infliximab to biosimilar CT-P13 in real-life: the weight of patient acceptance. Joint Bone Spine 2017. 10.1016/j.jbspin.2017.10.003 [Epub ahead of print 14 Nov 2017].

8 Nguyen E, Weeda ER, Sobieraj DM, et al. Impact of non-medical switching on clinical and economic outcomes, resource utilization and medication-taking behavior: a systematic literature review. Curr Med Res Opin 2016;32:1281-90.

9 Weinblatt ME, Kremer JM, Bankhurst AD, et al. A trial of etanercept, a recombinant tumor necrosis factor receptor:Fc fusion protein, in patients with rheumatoid arthritis receiving methotrexate. $N$ Engl J Med 1999;340:253-9.

10 Matsuno H, Tomomitsu M, Hagino A, et al. Phase III, multicentre, double-blind, randomised, parallel-group study to evaluate the similarities between LBEC0101 and etanercept reference product in terms of efficacy and safety in patients with active rheumatoid arthritis inadequately responding to methotrexate. Ann Rheum Dis 2018;77:488-94

11 Scherlinger M, Schaeverbeke T. Response to: 'Switching from the bio-originators to biosimilar: is it premature to recommend this procedure?' by Cantini and Benucci. Ann Rheum Dis 2019;78:e24

12 Tweehuysen L, van den Bemt BJF, van Ingen IL, et al. Subjective complaints as the main reason for biosimilar discontinuation after open-label transition from reference infliximab to biosimilar infliximab. Arthritis Rheumatol 2018;70:60-8. 